\title{
STRATEGI PEMERINTAH DESA DALAM PEMBERDAYAAN KELOMPOK TANI DI DESA TAMBE KECAMATAN BOLO KABUPATEN BIMA (Studi kasus di Desa Tambe Kecamatan Bolo Kabupaten Bima)
}

\section{Strategy of the Village Government in Empowering Farmer's groups in the Village of Tambe, Sub District Bolo, Regency of Bima}

\author{
Edi Irawan \\ Program Studi Ekonomi Pembangunan, Fakultas Ekonomi Dan Bisnis Universitas Teknologi Sumbawa \\ e-mail: edihaidah@gmail.com
}

\begin{abstract}
This study aims to know about the implementation of the village government strategies in community empowerment in Tambe Village. This is based on the large number of Tambe villagers who work as farmers and supported by the geography and topography of the village which is suitable for the agricultural sector. This research is using qualitative methods with descriptive approach. The results of the study shows that the village government strategy is not applied properly and get stagnant. There are several farmer groups in this village that are not empowered by the government. In addition, human resource capacity is also influential in the development of farmer groups in Tambe Village.
\end{abstract}

Keywords: Strategy, village government, empowerment, farmer group

\begin{abstract}
ABSTRAK
Penelitian ini bertujuan untuk mengetahui tentang penerapan strategi pemerintah desa dalam pemberdayaan masyarakat di Desa Tambe. Hal ini didasari karena banyaknya masyarakat desa Tambe yang berprofesi sebagai petani dan didukung dengan keadaan geografi dan topografi dari desa Tambe itu sendiri yang cocok untuk dijadikan area pertanian. Penelitian ini menggunakan metode penelitian kualitatif yang bersifat deskriptif. Dari hasil penelitian didapati strategi pemerintah desa tidak diterapkan dengan baik dan berjalan ditempat. Ada beberapa kelompok tani di desa ini yang tidak diberdayakan oleh pemerintah. Selain faktor pemerintah, kemampuan sumberdaya manusia juga berpengaruh dalam perkembangan kelompok tani di Desa Tambe.
\end{abstract}

Keywords: Strategi, pemerintah desa, pemberdayaan, kelompok tani

\section{Pendahuluan}

Dalam UU No.6 Tahun 2014 tentang Desa yang merujuk pada Peraturan Pemerintah No.47 Tahun 2015, pelaksanaan Undang-Undang tersebutpada pasal 1 ayat 1 memberikan kesempatan kepada masyarakat desa untuk mengatur dan mengurus rumah tangganya sendiri dengan persyaratan yang diamanatkan serta memperhatikan potensi dan keanekaragaman daerah dalam sistem Negara Kesatuan Republik Indonesia.

Pemberdayaan masyarakat terlebih khusus untuk kelompok tani merupakan upaya untuk meningkatkan kualitas sumber daya manusia (SDM) dengan membentuk dan merubah perilaku masyarakat melalui pengembangan potensi-potensi yang dimiliki. Petani dalam hal ini adalah pelaku utama yang harus diberdayakan. Paradigma strategi pemberdayaan masyarakat petani perlu dirancang dengan cara melibatkan partisipasi masyarakat petani secara optimal. Orientasi pemberdayaan masyarakat haruslah membantu sasaran (petani) agar mampu mengembangkan diri atas dasar inovasi-inovasi yang ada, ditetapkan secara partisipatoris yang berorientasi pada kebutuhan masyarakat dan hal-hal yang bersifat praktis, baik dalam bentuk layanan individu atau kelompok.

Usaha tani di Indonesia didominasi oleh usaha tani keluarga skala kecil yang sangat lemah dalam berbagai bidang, dengan kata lain tidak dapat berkembang mandiri secara dinamis. Petani kecil sangat tergantung pada golongan petani lahan luas atau pedagang untuk 
memperoleh asset produktif (lahan, peralatan), modal kerja dan perolehan sarana produksi

Pemberdayaan petani melalui kelembagaan kelompok tani merupakan salah satu metode pemberdayaan masyarakat yang tepat untuk memungkinkan mereka dapat meningkatkan kualitas hidupnya. Lembaga kecil ini merupakan suatu bentuk organisasi kerja sama yang membuat masyarakat mampu mengembangkan respon yang sesuai dengan logika dan menjadi suatu wadah yang menyatukan para petani secara horizontal maupun vertikal (Suradisastra 2006:34). Tahun 2007 awalnya jumlah kelompok tani yang terbentuk di Desa Tambe berjumlah 4 kelompok (Tambora, indah,wangi dan jaya) namun dalam perjalanannya saat ini hanya tinggal 1 yang aktif yaitu kelompok tani Jaya.

Dalam pengamatan penulis, perkembangan dan perjalanan kelompok tani di Desa Tambe belum sesuai dengan harapan. Hal ini dapat dilihat pada kelengkapan alat-alat pertanian yang ada, antara lain seperti ketidak tersediaannya sawah sendiri atau lahan pertanian untuk tes bibit, lumbung padi, alat pengering padi, alat rontok padi, kios saprodi (penyedia benih/bibit unggul, pupuk, dan obat-obatan), traktor, alat penyemprot hama dan sebagainya, serta pula akses permodalan usahatani yang masih sangat minim dan infrastrukturinfrastruktur yang kurang mendukung sehingga memerlukan perbaikan seperti jaringan irigasi, dan alat komunikasi, serta eksistensi kelembagaan petani yang sebagian besar masih sebatas formalitas. Adapun maksud dari eksistensi kelembagaan yang masih bersifat formalitas disini adalah keaktifkan pertemuanpertemuan dari kelompok tani yang ada.

Berdasarkan uraian diatas, peneliti merasa tertarik untuk melakukan penelitian agar bisa membantu pemerintah desa untuk menjadi lebih baik lagi dalam merencanakan serta mengevaluasi setiap program kerja yang ada dan menjadikan Desa Tambe maju dalam pembangunan desa melalui hasil-hasil sektor pertanian sehingga manfaatnya dapat dirasakan oleh pemerintah sendiri dan tentunya terlebih untuk masyarakat.

Adapun tujuan dari penelitian ini adalah untuk mengetahui strategi pemerintah desa dalam meningkatkan perberdayaan kepada masyarakat khususnya kelompok tani di Desa Tambe Kecamatan Bolo.

\section{Tinjauan Pustaka}

\section{Konsep Strategi dan Pemerintah Desa}

Menurut Kamus Umum Bahasa Indonesia,strategi adalah (1) ilmu dan seni menggunakan semua sumber daya bangsa-bangsa untuk melaksanakan kebijaksanaan tertentu (2) rencana yang cermat mengenai kegiatan untuk mencapai sasaran khusus; strategi adalah pendekatan secara keseluruhan yang berkaitan dengan pelaksanaan gagasan, perencanaan, dan eksekusi sebuah aktivitas dalam kurun waktu tertentu.Menurut BussinesDictionary, pengertian strategi adalah metode atau rencana yang dipilih untuk membawa masa depan yang diinginkan, seperti pencapaian tujuan atau solusi untuk masalah, strategi juga adalah seni dan ilmu perencanaan dan memanfaat sumber daya untuk penggunaan yang paling efisien dan efektif.Menurut B.N. Marbun , ( 2003 : 341 ) bahwa "Strategi adalah rencana yang cermat mengenai kegiatan untuk mencapai sasaran khusus dan saling hubungan dalam hal waktu dan ukuran". Pemahaman yang baik mengenai konsep strategi dan konsep-konsep lain yang berkaitan, sangat menentukan suksesnya strategi yang disusun.

Menurut Undang-Undang Nomor 6 Tahun 2014 tentang Desa, “ Desa atau yang disebut dengan nama lain, selanjutnya disebut desa, adalah kesatuan masyarakat hukum yang memiliki batas-batas wilayah yang berwenang untuk mengatur dan mengurus kepentingan masyarakat setempat, berdasarkan asalusul dan adat-istiadat setempat yang diakui dan dihormati dalam sistem Pemerintahan Negara Kesatuan Republik Indonesia”. Pengertian desa dari sudut pandang sosial budaya dapat diartikan sebagai komunitas dalam kesatuan geografis tertentu dan antar mereka saling mengenal dengan baik dengan corak kehidupan yang relatif saling membutuhkan dan banyak bergantung secara langsung dengan alam. Oleh karena itu, desa diasosiasikan sebagai masyarakatyang hidup secara sederhana pada sektor agraris, mempunyai ikatan sosial, adat dan tradisi yang kuat, bersahaja, serta tingkat pendidikan yang rendah.

\section{Konsep Pemberdayaan}

Pemberdayaan dan memberdayakan yang mengandung dua pengertian yaitu : pengertian pertama adalah to give power or authority to, dan pengertian kedua berarti to give ability to or enable. Dalam pengertian pertama diartikan sebagai memberi kekuasaan, mengalihkan kekuatan atau mendelegasikan otoritas ke pihak lain.Sedang dalam pengertian kedua, diartikan sebagai upaya untuk memberikan kemampuan atau keberdayaan.Pengertian pemberdayaan menekankan pada aspek pendelegasian kekuasaan, memberi wewenang, atau pengalihan kekuasaan kepada individu atau masyarakat sehingga mampu mengatur diri dan lingkungannya sesuai dengan keinginan, potensi, dan kemampuan yang dimilikinya.

\section{1) Tujuan dan Strategi/Cara Pemberdayaan Masyarakat}

Tujuan pemberdayaan masyarakat adalah memampukan dan memandirikan masyarakat terutama dari kemiskinan dan keterbelakangan, kesenjangan, ketidak berdayaan. Kemiskinan dapat dilihat dari indikator pemenuhan kebutuhan dasar yang belum mencukupi/layak. Kebutuhan dasar itu, mencakup 
pangan,papan, pakaian, kesehatan, pendidikan, dan transportasi.

Sedangkan keterbelakangan, misalnya produktivitas yangrendah, sumberdaya manusia yang lemah, terbatasnya akses pada tanah padahalketergantungan pada sektor pertanian masih sangat kuat, melemahnya pasar-pasarlokal/tradisional karena dipergunakan untuk memasok kebutuhan perdagangan internasional. Menurut Usman (Usman,2004:36), strategi atau kegiatan yang dapat diupayakan untuk mencapai tujuanpemberdayaan masyarakat yang dapat menjadi pertimbangan untuk dipilih dan kemudian diterapkan antara lain :

\section{a. Strategi 1 : Menciptakan Iklim, Memperkuat Daya, dan Melindungi}

Dalam upaya memberdayakan masyarakat dapat dilihat dari tiga sisi, yaitu: Pertama, menciptakan suasana atau iklim yang memungkinkan potensi masyarakatberkembang (enabling). Kedua, memperkuat potensi atau daya yang dimiliki masyarakat (empowering). Ketiga, memberdayakan mengandung pula arti melindungi.

\section{b. Strategi 2 : Program Pembangunan Pedesaan}

Pemerintah di negara-negara berkembang termasuk Indonesia telah mencanangkan berbagai macam program pedesaan, yaitu (1) pembangunan pertanian, (2) industrialisasipedesaan, (3) pembangunan masyarakat desa terpadu, dan (4) strategi pusat pertumbuhan (Usman, 2004). Program

pembangunan pertanian, merupakan program untuk meningkatkan outputdan pendapatan para petani. Juga untuk menjawab keterbatasan pangan di pedesaan,bahkan untuk memenuhi kebutuhan dasar industri kecil dan kerumahtanggaan, serta untuk memenuhi kebutuhan ekspor produk pertanian bagi negara maju.Program industrialisasi pedesaan yang berbasis pertanian, merupakan peningkatan nilai tambah suatu produk untuk akhirnya dapat meningkatkan nilai jual dari produk tersebut sehingga dapat meningkatkan pendapatan masyarkat.Program pembangunan masyarakat terpadu, tujuan utamanya untuk meningkatkan produktivitas, memperbaiki kualitas hidup penduduk dan memperkuat kemandirian.

Enam unsur dalam pembangunan masyarakat terpadu, yaitu:pembangunan pertanian dengan padat karya, memperluas kesempatan kerja, intensifikasi tenaga kerja dengan industri kecil, mandiri dan meningkatkan partisipasi dalampengambilan keputusan, mengembangkan perkotaan yang dapat mendukung pembangunan pedesaan, membangun kelembagaan kelompok tani yang dapat melakukan koordinasi proyek multisektor (Usman, 2004).Selanjutnya program strategi pusat pertumbuhan, merupakan alternatif untuk menentukan jarak ideal antara pedesaan dengan kota, sehingga kota benar-benar berfungsi sebagai pasaratau saluran distribusi hasil produksi. Cara yang ditempuh adalah membangun pasar didekat desa.Pasar ini difungsikan sebagai pusat penampungan hasil produksi desa, dan pusat informasi tentang hal-hal berkaitan dengan kehendak konsumen dan kemampuan produsen.

\section{2) Tugas Pemberdayaan Masyarakat}

Pemberdayaan masyarakat bisa dilakukan oleh banyak elemen: pemerintah,perguruan tinggi, lembaga swadaya masyarakat, partai politik, lembaga donor, aktor-aktor masyarakat sipil, atau oleh organisasi masyarakat lokal sendiri. Birokrasi pemerintah tentu saja sangat strategis karena mempunyai banyak keunggulan dan kekuatan yang luar biasa ketimbang unsur-unsur lainnya: mempunyai dana, aparat yang banyak, kewenangan untuk membuat kerangka legal, kebijakan untuk pemberian layanan publik, dan lainlain. Proses pemberdayaan bisa berlangsung lebih kuat, komprehensif dan berkelanjutan bila berbagai unsur tersebut membangun kemitraan dan jaringan yang didasarkan pada prinsip saling percaya dan menghormati.

Dalam setiap desa perlu di bentuk kemitraaan dan pemerintahan desa perlu didorong untuk bersama-sama melakukan pemberdayaan masyarakat.Kemitraan mampu mendorong percepatan kemapanan ekonomi masyarakat, berfungsi secara efektif pemerintahan desa (sistem politik lokal), keteladanan pemimpin (elit lokal), dan partisipasi aktif masyarakat,maka kemampuan dan kemandirian masyarakat dalam pembangunan akan dapat terwujud.

\section{Strategi Pemerintah Desa Dalam Memberdayakan Masyarakat}

Pelaksanaan mengenai tugas dan fungsi seorang Kepala Desa dalam pemerintahan merupakan salah satu bentuk kegiatan aparat pemerintah dalam upaya meningkatkan kesejahteraan masyarakat, sebagaimana tujuan dari penelitian ini adalah untuk memberikan deskripsi mengenai pelaksanaan fungsi tersebut. Untuk itu dalam melaksanakan tugasnya aparat desa mempunyai fungsi :

a. Kegiatan dalam rumah tangganya sendiri

b. Menggerakkan partisipasi masyarakat

c. Melaksanakan tugas dari pemerintah di atasnya

d. Keamanan dan ketertiban masyarakat

e. Melaksanakan tugas-tugas lain yang diberikan oleh pemerintah di atasnya

Untuk menyelenggarakan fungsi tersebut di atas maka seorang Kepala Desa harus mengusahakan: 
a. Terpenuhinya kebutuhan esensial masyarakat

b. Tersusunnya rencana dan pelaksanaan pembangunan sesuai dengan kemampuan setempat

c. Terselenggaranya program yang berkelanjutan

d. Adanya peningkatan perluasan kesempatan kerja

\section{Metode Penelitian}

\section{Jenis Penelitian}

Jenis penelitian ini menggunakan jenis atau metode penelitian kualitatif. Model penelitian kualitatif ini biasanya digunakan dalam pengamatan dan penelitian sosial. Metodologi kualitatif sebagai prosedur penelitian yang menghasilkan data deskripsi berupa informasi tertulis dan lisan dari seseorang dan prilaku yang dapat diamati(Sugiyono, 2007:15).

Penelitian ini merupakan penelitian deskriptif yaitu jenis penelitian yang memberikan gambaran atau uraian suatu keadaan pada objek yang diteliti. Data yang terkumpul akan dianalisa secara kualitatif. Jenis data kualitatif adalah data yang dinyatakan dalam bentuk kata, kalimat dan gambar (Sugiyono, 2007:15).

\section{Fokus Penelitian}

Adapun fokus penelitian dalam hal ini adalah strategi pemerintah desa dalam pemberdayakan kelompok tani Jaya yang ada di Desa Tambe. Untuk melihat strategi yang dijalankan oleh pemerintah desa Tambe dalam pemberdayaan kelompok tani maka penulis memfokuskan penelitian pada :

Strategi pemerintah desa dalam pemberdayaan kelompok tani yang ada di Desa Tambe Kecamatan Bolo dengan teori yang dikemukakan oleh (Usman (2004:37):

a. Menciptakan suasana atau iklim yang memungkinkan potensi masyarakat petani dapat berkembang.

b. Memperkuat potensi atau daya yang dimiliki masyarakat (empowering).

c. Melindungi masyarakat/kelompok tani.

\section{Informan}

a. Hukum Tua

b. Dua (2) Pengurus Kelompok Tani

c. Tiga (3) Tokoh Masyarakat

d. Lima (5) Petani dan Masyarakat

\section{Teknik Pengumpulan Data}

Langkah berikutnya wawancara kepada keyperson yang dirasa perlu dan mempunyai kapasitas dalam pemberdayaan kelompok tani untuk mendapatkan data sesuai dengan kebutuhan peneliti. Wawancara yaitu merupakan bentuk komunikasi antara dua orang, melibatkaan seseorang yang ingin memperoleh informasi dari seorang lainnya dengan mengajukan pertanyaan-pertanyaan, berdasarkan tujuan tertentu.
Dalam kegiatan wawancara ada yang disebut dengan wawancara tak terstuktur. Wawancara tak terstruktur sering disebut wawancara mendalam bersifat luwes, susunan pertanyaannyadan susunan kata-kata dalam setiap pertanyaan dapat diubah pada saat wawancara, disesuaikan dengan kebutuhan dan kondisi saat wawancara, termasuk karakteristik sosial budaya (agama, suku, gender, usia, tingkat pendidikan, pekerjaan, dan lain sebagainya) responden yang dihadapi.

Studi dokumentasi digunakan oleh peneliti sebagai bahan pendukung yang berkaitan dengan penelitian ini yang diperoleh melalui arsip-arsip dan dokumendokumen dari kantor terkait. Studi dokumentasi yaitu teknik pengumpulan data yang tidak langsung ditujukan kepada subyek penelitian.

\section{Teknik Analisis Data}

Dalam menganalisa data kualitatif, penulis mengambil langkah sebagai berikut:

1. Data awal yang telah diperoleh dari lapangan, dilakukan proses penelitian atau data yang di dapatkan dari lapangan dikaji/dilakukan perbandingan sehingga saling berhubungan satu sama lain dengan menggunakan proses berpikir yang rasional, penuh analisis, kritik dan logis dengan mencari persamaan dan perbedaannya.

2. Setelah itu penulis memberikan interpretasi yang bersifat rasional, analitik, kritik dan logis mengenai penelitian ini berdasarkan data yang telah diperoleh.

\section{Hasil Penelitian dan Pembahasan}

\section{Temuan Penelitian}

Pada bagian ini akan dibahas tentang analisa data, dimana data yang diperoleh dari hasil penelitian melalui wawancara kepada informan. Menganalisa data merupakan suatu upaya untuk menata dan mengelompokkan data menjadi suatu bagian-bagian tertentu menurut kelompok data jawaban informan.Analisa data yang dimaksud adalah suatu interpretasi langsung berdasarkan data dan informasi yang diperoleh di lapangan dengan tetap berpedoman kepada masalah dan tujuan penelitian.Pengkajian kualitatif dalam menyelidiki aktivitas kepala desa yang dalam hal ini pemerintah desa merupakan landasan dasar memahami sejauh mana strategi pemerintah desa dalam pemberdayaan kelompok tani Desa Tambe Kecamatan Bolo Kabupaten Bima.

Dalam penyelenggaraan pemerintahan desa, pemerintah desa dalam hal ini kepala desa dan perangkat desa dalam meningkatkan pemberdayaan terhadap kelompok tani harus mengikut sertakan asasasas umum pemerintahan yang baik. Memberdayakan masyarakat adalah upaya meningkatkan harkat dan 
martabat lapisan masyarakat yang dalam kondisi sekarang tidak mampu melepaskan diri dari kemiskinan dan keterblakangan dan dalam kata lain memberdayakan adalah memampukan dan memandirikan masyarakat yang terangkum dalam penelitian di tengah-tengah masyarakat lewat pertanyaan sebagai berikut :

\section{1) Strategi Pemerintah Desa dalam Pemberdayaan Kelompok Tani.}

Data yang dikumpulkan berdasarkan penelitian melalui interview dengan beberapa informan, penulis menyimpulkan bahwa Pemerintah desa terkesan tidak memilki strategi dalam mendorong pemberdaayaan kelompok tani di Desa Tambe. Sebagaimana seperti yang diungkapkan oleh salah satu informan dengan inisial SD,umur 45 Tahun, pekerjaan pengurus kelompok tani, pendidikan SMA :"Pemerintah desa terkesan tidak memiliki strategi dalam memberdayakan kelompok tani atau bisa di katakan kurang peduli terhadap kelompok tani yang ada di desa Tambe ".

Pada saat penulis mencoba lebih jauh lagi mencari tahu terkait dengan minimnya kepedulian pemerintah desa dalam mendorong pengembangan dan pemberdayaan kelompok tani, Kepala Desa Tambe ZU, umur 45 tahun, (Hukum tua) mengatakan: "Kami memang tidak secara umum dan menyeluruh melakukan pemberdayaan bagi kelompok tani, tapi sejauh ini kami sudah berusaha melakukan yang terbaik. Tapi kami juga terbatas dalam soal anggaran untuk bagaimana melakukan pemberdayaan kelompok tani baik itu pelatihan, pendampingan bahkan penyediaan fasilitas dan alat-alat pertanian lainnya. Namun perlu diketahui untuk penyediaan fasilitas pertanian sudah ada yang kami berikan, antara lain 3 (Tiga) unit alat traktor dan tidak hanya itu kami juga sudah memberikan bantuan seperti pupuk dan obat pembasmi hama. Tapi lagi-lagi perlu disadari bahwa untuk mengembangkan usahausaha pertanian tidak cukup hanya dilakukan oleh kami selaku pemerintah desa melainkan perlu ada kerjasama dari berbagai pihak bahkan selebihnya dari Instansi terkait, (Dinas pertanian) dan seluruh stockholder pemerintah terlebih khusus kerja sama dari masyarakat tentunya,karena terkadang kami mengalami kendala yang disebabkan kurangnya kerjasama dari masyarakat.",

Berdasarkan kajian mendalam yang diuraikan pada bagian ini maka penulis tiba pada sebuah konstruksi pemahaman bahwa pemerintah desa Tambe tidak memiliki strategi baik itu dalam pola dan pendekatan tradisional maupun dalam pola pendekatan tranformatif.

\section{2) Pemerintah Desa dalam Membina Hubungan dengan Kelompok Tani.}

Dalam konteks pemberdayaan sosial kerap dan banyak kali selalu saja menyentuh berbagai dimensi aspek kehidupan dan salah satu faktor penting dalam pola pengembangan pemberdayaan sosial adalah bagaimana membangun pola hubungan yang holistik dan humanis, serta relevan dalam konteks peningkatan produktivitas.

Pola hubungan yang dimaksudkan pada bagian ini adalah dimensi dan pola komunikasi yang terbangun antara pemerintah dan kelompok tani dalam rangka memberikan informasi yang bersifat edukatif dan tranformatif untuk meningkatan pemberdayaan masyarakat tani. Setelah melakukan penelitian melalui beberapa informan dan berbagai referensi melalui penelusuran kondisi dilapangan, menunjukan bahwa pola hubungan komunikasi antar pemerintah desa dan kelompok tani kurang terbangun. Hal ini kemudian diperkuat dengan apa yang disampaikan oleh salah satu Informan dengan inisial: M.S, umur 47 Tahun, pekerjaan Tani Pendidikan SMA : “ Selama ini kami melihat bahwa pemerintah desa kurang begitu perhatian dan jarang melibatkan kami dalam memberikan pendapat untuk kelangsungan kelompok tani, apalagi dalam hal memberikan informasi,atau sosialisasi yang ada hubungan dengan pertanian. Selama ini kami hanya berusaha sendiri untuk bisa mengembangkan usaha-usaha kami “.

\section{3) Strategi Pemerintah Desa dalam Upaya Mensejaterakan Kelompok Tani.}

Esensi dari sebuah pencapaian penyelenggaraan pemerintahan adalah untuk mencapai kesejateraan masyarakat.Kesejahteraan merupakan faktor utama untuk mengukur keberhasilan suatu pemerintahan.Dalam konteks strategi pemerintah dalam memberdayakan kelompok tani makasalah satu aspek penting yang perlu diperhatikan adalah soal kesejateraan.

Pada bagian ini akan diuraikan hasil wawancara yang penulis lakukan dengan beberapa informan yang dianggap mampu dan cakap untuk memberikan informasi ilmiah terkait dengan strategi pemerintah dalam upaya mensejahterakan kelompok tani, sebagaimana yang diungkapkan oleh salah satu informan dengan inisial A.L. Umur 45 tahun, pekerjaan Tani, pendidikan SMA, menturkan bahwah : "Perhatian pemerintah dalam upaya mensejahterakan kelompok tani masih belum dirasakan. Dan saya kira pemerintah kurang kurang mampu memiliki stretegi untuk mendorong kesejahteraan kami sebagai petani, hal ini bisa dilihat bahwa pemerintah kurang melakukan pengawasan terhadap usaha-usaha pertanian, bahkan pemerintah juga kurang melakukan lobby untuk mendapatkan bantuan dari pemerintah daerah melalui dinas terkait. Jadi sejauh ini kami 
melihat bahwa pemerintah desa perlu ada perhatian yang lebih khusus dan berkesinambungan bagi kelompok tani. Karena kalau ini hanya dibiarkan akan berdampak bagi kesejahteraan kelompok tani dan tentunya sangat merugikan ".

\section{Pembahasan}

Pemberdayaan dalam wacana pembangunan masyarakat selalu dihubungkan dengan konsep kemandirian,partisipasi, hubungan kerja / jaringan kerja, dan keadilan sosial. Karena hal ini merupakan, persyaratan yang memungkinkan setiap orang dapat memiliki kekuatan yang menjadi modal dasar bagi pelaksanaan existensi sebuah kelompok dan komunitas. Berangkat dari paradigm inilah kemudian pemberdayaan itu menjadi aspek dan ikon penting dalam mendorong kesejahteraan sosial bagi masyarakat. Dalam konteks pemberdayaan kelompok tani maka sedikitnya ada tiga langkah untuk menciptakan iklim dan suasana pemberdayaan kelompok tani yaitu: Pertama, upaya itu harus terarah (targetted). Ini yang secara populer disebut pemihakan. Ia ditujukan langsung kepada yang memerlukan, dengan program yang dirancang untuk mengatasi masalahnya dan sesuai kebutuhannya.

Kedua, program ini harus langsung mengikutsertakan atau bahkan dilaksanakan oleh masyarakat yang menjadi sasaran. Mengikutsertakan masyarakat yang akan dibantu mempunyai beberapa tujuan, yakni supaya bantuan tersebut efektif karena sesuai dengan kehendak dan kemampuan serta kebutuhan mereka. Selain itu sekaligus meningkatkan keberdayaan (empowering) masyarakat dengan pengalaman dalam merancang, melaksanakan, mengelola, dan mempertanggungjawabkan upaya peningkatan diri dan ekonominya.

Ketiga, menggunakan pendekatan kelompok, karena secara sendiri-sendiri masyarakat miskin sulit dapat memecahkan masalah-masalah yang dihadapinya. Juga lingkup bantuan menjadi terlalu luas kalau penanganannya dilakukan secara individu. Karena itu seperti telah disinggung di muka, pendekatan kelompok adalah yang paling efektif, dan dilihat dari penggunaan sumber daya juga lebih efisien. Di samping itu kemitraan usaha antara kelompok tersebut dengan kelompok yang lebih maju harus terus-menerus di bina dan dipelihara secara saling menguntungkan dan memajukan. Dalam upaya ini perlu dilibatkan semua lapisan masyarakat, baik pemerintah maupun dunia usaha dan lembaga sosial dan kemasyarakatan, serta tokohtokoh dan individu-individu yang mempunyai kemampuan untuk membantu.

Dalam konteks pemberdayaan petani perlu dilakukan kegiatan-kegiatan mengembangkan kelompok tani sebagai lembaga tani yang tangguh, terutama di bidang ekonomi, sosial, dan budaya melalui kelompok tani ini dengan menfasilitasi proses pembelajaran petani dan masyarakat pelaku agribisnis, membantu menciptakaniklim usaha yang menguntungkan, memberikan rekomendasi dan mengusahakan aksesakses petani ke sumber-sumber informasi dan sumberdaya lainnya demi memecahkan masalah kelompok tani, menjadikan lembaga penyuluhan pertanian sebagai wadah mediasi dan intermediasi terutama menyangkut teknologi untuk kepentingan agribisnis. Selanjutnya pada bagian ini penulis mencoba menganalisis hasil penelitian dengan menyesuaikan kondisi objektif dilapangan dengan menggunakan pendekatan teori Strategi pemberdayaan yang dikemukan oleh (Sunyoto Usman) :

\section{1) Menciptakan Iklim}

Setelah mencermati kondisi objektif dilapangan dan menyesuaikan dengan teori yang diuraikan diatas maka penulis menyimpulkan bahwah pemerintah desa Popontolen tidak memiliki strategi dalam upaya memberdayakan kelompok tani sehingga kemudian kondisi iklim dan suasana dinamika kelompok tani belum mencerminkan hasil yang produktif demi kesejateraan mereka. Sebagaimana apa yang disampaikan oleh informan dengan inisial : M, Umur 47 Tahun, pekerjaan Petani, pendidikan SMA : Mengatakan bahwah :" Pemerintah kurang memiliki perhatian dibidang pertanian, hal ini bisa dilihat dari perilaku pemerintah yang kurang mengusahakan untuk memberikan pengertian dan motivasi serta menciptakan suasana pertaniaan yang mengairahkan bagi petani untuk mendorong hasil pertanian supaya dikemudian hari bisa lebih produktif."

\section{2) Memperkuat Daya}

Pemberdayaan bukan hanya meliputi penguatan individu anggota masyarakat,tetapi juga pranatapranatanya.Demikian pula pembaharuan institusiinstitusi sosial danpengintegrasiannya ke dalam kegiatan pembangunan serta peranan masyarakat didalamnya. Yang terpenting disini adalah peningkatan partisipasi rakyat dalam prosespengambilan keputusan yang menyangkut diri dan masyarakatnya. Oleh karena itu,pemberdayaan masyarakat amat erat kaitannya dengan pemantapan, pembudayaan,pengamalan demokrasi.Sebagaimana apa yang diungkapkan $H$, umur 35 tahun, pekerjaan petani, pendidikan SMA: "Kurang adanya upaya dari pemerintah untuk meningkatkan daya atau potensi kelompok tani, baik dalam bidang ekonomi, sosial maupun budaya. Mestinya pemerintah harus megupayakan akses untuk kelompok tani melalui sosialisasi, pemberian bantuan modal, obat-obatan pemberantas hama, pembuatan irigasi untuk mengairi sawa, dorongan pengaktifan lembaga kelompok tani didesa, bahkan bantuanbantuan lainnya seperti pengadaan alat pengolah ". 


\section{3) Melindungi}

Memberdayakan mengandung pula arti melindungi. Dalam proses pemberdayaan, harus dicegah yang lemah menjadi bertambah lemah, oleh karenakurangberdaya dalam menghadapi yang kuat. Pemihakan yang dimaksud adalah segala upaya yang dilakukan harus terarah atau tepat ditujukan kepada yang memerlukan.Melindungi harusdilihat sebagai upaya untuk mencegah terjadinya persaingan yang tidak seimbang.Pemberdayaan masyarakat bukan membuatmasyarakat menjadi makin tergantung pada berbagai program pemberian (charity).Dengan demikian tujuan akhirnya adalahmemandirikan masyarakat, memampukan, dan membangun kemampuan untuk memajukandiri ke arah kehidupan yang lebih baik secara berkesinambungan. Penulis mewawancarai seorang pengurus kelompok tani Wangi dan beliau mengatakan: "seharusnya pemerintah desa sebagai pelindung bagi kelompok-kelompok tani yang ada melakukan apa yang seharusnya dilakukan sebagai pemerintah, tidak membiarkan kelompokkelompok tani yang sudah ada berakhir tidak jelas".

\section{Kesimpulan}

Berdasarkan uraian diatas, dapat disimpulkan bahwa:

1. Pemerintah Desa Tambe dalam hal ini tidak memiliki strategi untuk memberdayakan kelompok tani, pemerintah hanya membiarkan kelompok-kelompok tani berjalan sendiri tanpa adanya pendampingan, perlindungan, serta kekuatan untuk kelompok tani maju berkembang dalam teknologi pertanian sehingga mereka hanya mengandalkan infrastrukturinfrastruktur lama yang ada di dalam desa sebagai media pendukung dalam proses pemberdayaan kelompok tani.

2. Pemerintah kurang peduli akan kesejahteraan petani di Desa Tambe, hal ini dilihat dari tidak adanya tindakan pemerintah dalam mengembangkan potensi-potensi yang ada didesa. Tidak adanya tindakan pemerintah ketika kelompok-kelompok tani berhenti beroperasi.

3. Respon yang tidak baik nampak dari masyarakat kepada pemerintah. Masyarakat sangat menyayangkan potensi-potensi yang diabaikan oleh pemerintah sehingga berimbas pada kurangnya partisipasi masyarakat dalam kegiatan atau program dari pemerintah dikarenakan sikap yang terlalu cuek dengan keberadaan kelompok tani oleh pemerintah.

\section{Saran}

Berdasarkan kesimpulan penelitian, maka penulis merekomendasikan saran-saran sebagai berikut :

1. Evaluasi kembali program yang sedang dijalankan untuk pengadaan infrastruktur pertanian sebagai media penunjang pemberdayaan kelompok tani. Ciptakan pula keadaan yang dapat menghidupkan potensi yang ada pada masyarakat sehingga mereka dapat menyadari potensi mereka masing-masing untuk berkembang dalam bidang pertanian, serta perhatikan jalinan komunikasi dengan masyarakat terlebih khusus dengan para petani yang tergabung dalam lembaga kelompok tani agar dapat memudahkan pemerintah desa menentukan strategi yang cermat dan tepat untuk kelangsungan program pemberdayaan kelompok tani yang demokratif;

2. Optimalkan potensi-potensi yang ada didesa terlebih khusus infrastruktur-infrastruktur penunjang kelompok tani seperti jalan kebun, jaringan irigasi, alat transportasi, alat komunikasi dan lain-lainnya yang memerlukan perbaikan dan perawatan agar kegiatan usahatani menjadi lancar sehingga produktivitas sektor pertanian menjadi meningkat;

3. Adakan media pendidikan formal maupun non formal bagi masyarakat petani melalui pergerakan keaktifan lembaga kelompok tani yang sempat terhenti,sehingga kegiatan tersebut dapat menjadi jembatan bagi pemerintah juga untuk memberikan pembinaan dan bimbingan yang konsisten, berkelanjutan serta tepat sasaran kepada masyarakat dengan selalu melibatkan mereka yakni supaya bantuan tersebut efektif karena sesuai dengan kehendak dan kemampuan serta kebutuhan mereka. Selain itu sekaligus meningkatkan keberdayaan (empowering) masyarakat dengan pengalaman dalam merancang, melaksanakan, mengelola, dan mempertanggungjawabkan upaya peningkatan diri dan ekonominya. dalam kegiatan tersebut,

4. Selalu adakan komunikasi secara intensif, dengan terjun langsung kelapangan untuk melakukan pendekatan yang intim dengan masyarakat petani yang keberadaannya mulai tidak aktif, ciptakan suasana kekeluargaan dengan mereka agar supaya perasaan kecewa yang dirasakan dapat terobati dengan sikap kepedulian yang ditunjukkan oleh pemerintah desa terhadap perkembangan kelompok tani secara berkelanjutan.

\section{Daftar Pustaka}

Koentjaraningrat (1990) Metode-Metode Penelitian Masyarakat. Jakarta, Gramedia.

Sutoro Eko,2002, Pemberdayaan Masyarakat Desa, Materi Diklat Pemberdayaan Masyarakat Desa, yang diselenggarakan Badan Diklat Provinsi Kaltim, Samarinda, Desember 2002. 
Artikel Michail Porter berjudul "What is Strategi?" yang dimuat dalam Business Review November- Desember 1996.

Moleong, J. Lexy. 2002. Metodologi Penelitian Kualitatif. Bandung: Remaja Rosdakarya.

J. Nasikun, 1995, Mencari Suatu Strategi Pembangunan Masyarakat Desa Berparadigma Ganda, dalam Jefta Leibo, Sosiologi Pedesaan, Yogyakarta : Andi Offset.

Suharto, Edi. 2006,Membangun Masyarakat Memberdayakan Rakyat.Bandung, Refika Aditama.

Usman,2004,Pembangunan dan Pemberdayaan Masyarakat, Yogyakarta : Pustaka Pelajar.

Sugiyono. Metode Penelitian Kualitatif Kuantitatif. Bandung: Alfabeta, 1998, cetakan kelima.

Ife, J.W, 1995. Community Development: Creating Community Altenatives-Vision, Analysis and Practice. Melbourne : Longman.

Pranarka dan Moeljarto, Mangatas. 1996,Pendidikan Pola Pemberdayaan Masyarakat dan Pemberdayaan Partisipasi Masyarakat dalam Pembangunan Sesuai Tuntutan Otonomi Daerah.

Juliantara, 2005, Pembaruan Desa Bertumpuh Pada Yang Terbawah. Jakarta, Gunung agung.
Kutut suwondo, 2005, Civil Society Di Aras Lokal: Perkembangan Hubungan Antara Rakyat dan Negara Di Pedesaan Jawa, Yogyakarta : Pustaka Belajar \& Percik.

Kedi Suradisastra. 2006. Revitalisasi Kelembagaan Untuk Percepatan Pembangunan Sektor Pertanian dalam Otonomi Daerah. Pusat Penelitian Sosial Ekonomi Bogor.

Jurnal Analisa Kebijakan Pertanian. Volume 4 No 4 Desember 2006.

Sumber Lain :

1)Undang-undang Dasar 1945

2)Undang-undang Nomor 6 tahun 2014 Tentang Desa

3)Peraturan Pemerintah Republik Indonesia Nomor 47 Tahun 2015tentangpelaksanaan UU Desa

4)UU Nomor 23 tahun 2014 tentang Pemerintah Daerah

5)Peraturan Menteri Dalam Negeri Republik Indonesia Nomor 7 Tahun 2007 tentang Kader Pemberdayaan Masyarakat, Bandung : Fokus Media.

http://google.com/KamusBesarBahasaIndonesia .

http://wikipedia.com/JurnalPemberdayaanMasyaraka $\underline{t}$.

http://google.com/KonsepStrategi

http://wikipedia.com/konseppemberdayaan 